\title{
The China
}

Quarterly

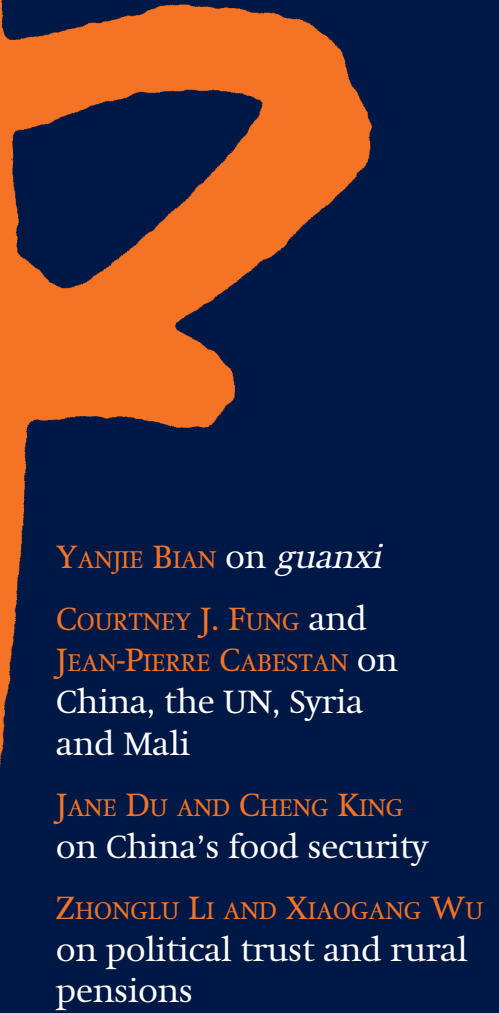




\section{The China Quarterly}

Published by Cambridge University Press for SOAS

University of London.

\section{The Editorial Office}

SOAS University of London, Thornhaugh Street,

Russell Square, London WC1H 0XG.

Tel. +44(0)207898 4063

Email: chinaq@soas.ac.uk

\section{Subscriptions}

The China Quarterly (ISSN 0305-7410) is published quarterly in March, June, September and December by Cambridge University Press, University Printing House, Shaftesbury Road, Cambridge CB2 8BS, UK/Cambridge University Press, 1 Liberty Plaza, Floor 20, New York, NY 10006, USA. The subscription price which includes electronic access and delivery by air where appropriate (but excluding VAT) of volumes 233 to 236 in 2018 is $£ 230.00$ (US $\$ 388.00$ in USA, Canada and Mexico) for institutions; $£ 46.00$ (US $\$ 80.00$ ) for individuals ordering direct from the publishers and certifying that the journal is for their personal use. Students can subscribe at $£ 21$ (US \$37). Single parts are $£ 65.00$ net (US \$109.00 in USA, Canada and Mexico) plus postage. EU subscribers (outside the UK) who are not registered for VAT should add VAT at their country's rate. VAT registered members should provide their VAT registration number. Japanese prices for institutions (including ASP delivery) are available from Kinokuniya Company Ltd, P.O. Box 55, Chitose, Tokyo 156, Japan.

Orders, which must be accompanied by payment, may be sent to a bookseller, subscription agent or direct to the publisher: Cambridge University Press, University Printing House, Shaftesbury Road, Cambridge CB2 8BS, UK. or in the USA, Canada and Mexico: Cambridge University Press, 1 Liberty Plaza, Floor 20, New York, NY 10006, USA.

Periodical postage paid at New York, NY and additional mailing offices. POSTMASTER: Send address changes to Cambridge University Press, 1 Liberty Plaza, Floor 20, New York, NY 10006, USA.

The current plus three back volumes are available from Cambridge University Press.

\author{
Advertising \\ Advertisements are welcomed and rates will be \\ quoted on request. Enquiries should be addressed to \\ Advertising Promoter, Journals Group, Cambridge \\ University Press, University Printing House, \\ Shaftesbury Road, Cambridge CB2 8BS, UK. \\ Tel +44 (0)1223 325757 Fax +44 (0)1223 325801 .
}

\section{Copying}

This journal is registered with the Copyright Clearance Center, 222 Rosewood Drive, Danvers, MA 01923, USA. Organizations in the USA who are also registered with the C.C.C. may, therefore, copy material (beyond the limits permitted by sections 107 and 108 of U.S. Copyright law) subject to payment to the C.C.C of the per copy fee of $\$ 12.00$. This consent does not extend to multiple copying for promotional or commercial purposes. Code 0305-7410/14. ISI Tear Sheet Service, 3501 Market Street, Philadelphia, PA 19104, USA, is authorized to supply single copies of separate articles for private use only. Organizations authorized by the Copyright Licensing Agency may also copy material subject to the usual conditions. For all other use, permission should be sought from Cambridge or from the American Branch of Cambridge University Press.

This journal is included in the Cambridge Journals Online Service which can be found at journals.cambridge.org. For further information on other Press titles access journals.cambridge.org.

(C) SOAS University of London, 2018 ISSN 0305-7410

Typeset by Techset Composition Ltd, Salisbury, UK. Printed in the United Kingdom by Bell \& Bain, Glasgow

This journal issue has been printed on FSC ${ }^{\mathrm{TM}}$-certified paper and cover board. FSC is an independent, non-governmental, not-for-profit organization established to promote the responsible management of the world's forests. Please see www.fsc.org for information. 


\section{The China Quarterly \\ an international journal for the study of China}

\section{September 2018 number 235}

State of the Field

597 The Prevalence and the Increasing Significance of Guanxi

Yanjie Bian

Articles

622 The Politics of Personnel Redundancy: The Non-leading Cadre System in the Chinese Bureaucracy Hon S. Chan and Jie Gao

644 Social Policy and Political Trust: Evidence from the New Rural Pension Scheme in China

Zhonglu Li and Xiaogang Wu

669 Acquired but Unvested Welfare Rights: Migration and Entitlement Barriers in Reform-Era China

Li Zhang and Meng Li

693 Separating Intervention from Regime Change: China's Diplomatic Innovations at the UN Security Council Regarding the Syria Crisis Courtney J. Fung

713 China's Involvement in Africa's Security: The Case of China's Participation in the UN Mission to Stabilize Mali

Jean-Pierre Cabestan

735 More than Peripheral: How Provinces Influence China's Foreign Policy Audrye Wong

758 Nationalism on Weibo: Towards a Multifaceted Understanding of Chinese Nationalism

Yinxian Zhang, Jiajun Liu and Ji-Rong Wen

784 "No CCP, No New China": Pastoral Power in Official Narratives in China Xiaoling Zhang, Melissa Shani Brown and David O'Brien

804 Unravelling China's Food Security Puzzle, 1979-2008

Jane Du and Cheng King

828 Stabilizing Forests and Communities: Accommodative Buffering within China's Collective Forest Tenure Reform

John Aloysius Zinda and Zhiming Zhang

849 Food Production Standards and the Chinese Local State: Exploring New Patterns of Environmental Governance in the Bamboo Shoot Industry in Lin'an

Kin Wing (Ray) Chan and Andrew Flynn

Book Reviews

876 The China Order: Centralia, World Empire, and the Nature of Chinese Power. By Fei-Ling Wang. Kevin Carrico

878 End of an Era: How China's Authoritarian Revival is Undermining Its Rise. By Carl Minzner. Patricia M. Thornton 
879 The Contentious Public Sphere: Law, Media, and Authoritarian Rule in China. By Ya-Wen Lei. Peter Lorentzen

881 The Power of Ideas: The Rising Influence of Thinkers and Think Tanks in China. By Cheng Li. Jane Hayward

882 Criminal Defense in China: The Politics of Lawyers at Work. By Sida Liu and Terence C. Halliday. Jianfu Chen

884 Justice: The China Experience. Edited by Flora Sapio, Susan Trevaskes, Sarah Biddulph and Elisa Nesossi; Chinese Legal Reform and the Global Legal Order: Adoption and Adaptation Edited by Yun Zhao and Michael Ng. Sida Liu

886 Mobilizing Without the Masses: Control and Contention in China. By Diana Fu. Regina Enjuto Martinez

888 The Emerging Industrial Relations of China. Edited by William Brown and Chang Kai. Henry Hailong Jia

890 City Making and Global Labor Regimes: Chinese Immigrants and Italy's Fast Fashion Industry. By Antonella Ceccagno. Gracia Liu-Farrer

891 Tourism and Prosperity in Miao Land: Power and Inequality in Rural Ethnic China. By Xianghong Feng. Jenny Chio

893 Chongqing's Red Culture Campaign: Simulation and Its Social Implications. By Mei Xiao. Xiaoye Zhang

895 China in the Mix: Cinema, Sound and Popular Culture in the Age of Globalization. By Ying Xiao. Chris Berry

896 China's Media Go Global. Edited by Daya Kishan Thussu, Hugo de Burgh and Andin Shi. Jonathan Sullivan

898 The Red Star and the Crescent: China and the Middle East. Edited by James Reardon-Anderson. Niv Horesh

900 Financing Healthcare in China: Towards Universal Health Insurance. By Sabrina Ching Yuen Luk. Christina Maags

901 Mental Health in China: Change, Tradition and Therapeutic Governance. By Jie Yang. Sonya E. Pritzker

904 The Good Child: Moral Development in a Chinese Preschool. By Jing Xu. Teresa Kuan

906 China's Conservative Revolution: The Quest for a New Order, 1927-1949. By Brian Tsui. Stephen R. MacKinnon

907 The Kaohsiung Incident in Taiwan and Memoirs of a Foreign Big Beard. By J. Bruce Jacobs. David Curtis Wright

909 The Art of Being Governed: Everyday Politics in Late Imperial China. By Michael Szonyi. Bruce Rusk

912 Books Received

915 Notes on Contributors

Please visit the journal's web site at www.cambridge.org and online at http://journals.cambridge.org/cqy

(C) SOAS University of London, 2018

Typeset by Techset Composition Limited

Printed by Bell \& Bain, Glasgow, UK 


\section{The China Quarterly}

\section{Editor}

Tim Pringle

\author{
Editorial Managers \\ Raphael Jacquet \\ Rowan Pease
}

\section{Editorial Assistants}

Joanne Phillips

Rosemary Williams

\section{Executive Committee}

Chris Berry, King's College London

Jane Duckett, University of Glasgow Dafydd Fell, SOAS University of London Peter Hays Gries, University of Manchester Jude Howell, London School of Economics Chun Lin, London School of Economics
Rachel Murphy, University of Oxford Elisa Oreglia, King's College London Lina Song, University of Nottingham Jonathan Sullivan, University of Nottingham Patricia M. Thornton, University of Oxford Fulong Wu, University College London

\section{Editorial Board}

Joel Andreas, Johns Hopkins University

Yanjie Bian, University of Minnesota I Xian Jiaotong University

Loren Brandt, University of Toronto

Donald C. Clarke, George Washington University Law School

Deborah Davis, Yale University

Joseph Fewsmith, Boston University

Vanessa Fong, Harvard Graduate School of Education

M. Taylor Fravel, Massachusetts Institute of Technology

Natascha Gentz, University of Edinburgh Bates Gill, Australian National University Lei Guang, San Diego State University Enze Han, University of Hong Kong Stevan Harrell, University of Washington Thomas Heberer, University of Duisburg-Essen

Sebastian Heilmann, Mercator Institute for China Studies (MERICS), Berlin

Carsten Holz, Hong Kong University of Science and Technology
Ching Kwan Lee, University of California, Los Angeles

Li Shi, Beijing Normal University

Melanie Manion, Duke University

Françoise Mengin, CERI-Sciences Po, Paris

Andrew Mertha, Johns Hopkins School of Advanced International Studies

Kevin O'Brien, University of California, Berkeley

Jean-Louis Rocca, CERI-Sciences Po, Paris

Lisa Rofel, University of California, Santa Cruz

Scott Rozelle, Stanford University

Gunter Schubert, Eberhard Karls University Tübingen

Helen Siu, Yale University

Xiaobing Tang, University of Michigan

Stig Thøgersen, Aarhus Universitet

Teresa Wright, California State University, Long Beach

Guobin Yang, University of Pennsylvania

\section{Former Editors}

\author{
Roderick MacFarquhar (1960-68) \\ David C. Wilson [Lord Wilson of Tillyorn] \\ (1968-74) \\ John Gittings (Acting Editor 1972) \\ Dick Wilson (1975-80) \\ Brian G. Hook (1980-91)
}

David Shambaugh (1991-96)

Richard Louis Edmonds (1996-2002)

Christopher B. Howe (Acting Editor 2005)

Julia Strauss (2002-11)

Chris Bramall (2011-16) 